\title{
Long-term effect of temperature and precipitation on radial growth in a threatened thermo-Mediterranean tree population
}

\author{
Magdalena Żywiec ${ }^{1,5} \cdot{\text { Elżbieta } \text { Muter }^{2} \text { - Tomasz Zielonka }}^{3} \cdot$ Miguel Delibes $^{4} \cdot$ \\ Gemma Calvo $^{4} \cdot$ Jose M. Fedriani $^{4,5}$
}

Received: 20 June 2016/Accepted: 27 September 2016/Published online: 11 October 2016

(C) The Author(s) 2016. This article is published with open access at Springerlink.com

\begin{abstract}
Key message Based on the first dendroclimatological analyses of the thermo-Mediterranean tree Pyrus bourgaeana, the positive relationship between the growth and climate (i.e., precipitation) has strengthened in recent decades.

Abstract The combined effect of climate change and habitat destruction and fragmentation threatens many plant populations and even entire communities in Mediterranean ecosystems. The Iberian pear, Pyrus bourgaeana Decne, a characteristic species of Mediterranean ecosystems, is threatened by both habitat and climate changes. We ask whether and how the growth of mature $P$. bourgaeana in the thermo-Mediterranean zone (i.e., altitude $<700 \mathrm{~m}$ ) has been affected by long-term climate changes during the last century in a fragmented landscape. Dendrochronological
\end{abstract}

Communicated by E. Liang.

Magdalena Żywiec

m.zywiec@botany.pl

1 Władysław Szafer Institute of Botany, Polish Academy of Sciences, ul. Lubicz 46, 31-512 Kraków, Poland

2 Department of Forest Biodiversity, Institute of Forest Ecology and Silviculture, Faculty of Forestry, University of Agriculture in Krakow, Al. 29 Listopada 46, 31-425 Kraków, Poland

3 Institute of Biology, Pedagogical University of Cracow, ul. Podchorążych 2, 30-084 Kraków, Poland

4 Department of Conservation Biology, Estacion Biologica de Doñana (EBD-CSIC), c/Americo Vespucio s/n, 41092 Seville, Spain

5 Centre for Applied Ecology "Prof Baeta Neves"(CEABNInBIO), School of Agronomy, University of Lisbon, Tapada da Ajuda, 1349-017 Lisbon, Portugal methods were used to find growth-climate relationships. We made the first dendroclimatological analyses and constructed a first 103-year tree-ring chronology (1905-2007) of this species. The tree-ring series revealed large growth variability. We found a clear, strong relationship between tree growth and climate, with annual precipitation being the most important climate factor enhancing radial growth. Our results also showed that warm autumns and winters positively affect growth. There was no temporal stability in the relationship between tree growth and climate. The most general trend was in the relationship between annual precipitation and tree growth: the decrease of rainfall in the last decades of the twentieth century was associated with a constant increase of the correlation coefficient. Water accumulated in the soil in autumn and winter proved to be a key factor augmenting tree growth in the following vegetation period. The climate-growth relationship in $P$. bourgaeana has strengthened in recent decades apparently due to decreased precipitation levels.

Keywords Climate change - Dendrochronology - Iberian pear - Pyrus bourgaeana . Thermo-Mediterranean zone . Tree growth

\section{Introduction}

Most models of climate change predict global warming associated with a marked variation of the level and spatiotemporal distribution of precipitation and temperature (IPCC 2014; Fischer and Schär 2010; Hoerling et al. 2012). Ecosystems of all climate zones are vulnerable to climate change, even in environments where water is not considered a limited resource (Allen et al. 2010), but according to climate models, the Mediterranean Basin is one of the 
world's climate change hotspots because of increases in the frequency, duration, and/or severity of droughts and heat stress (IPCC 2014; Luterbacher et al. 2012; Anderegg et al. 2013; Barbeta et al. 2013). Moreover, land-use change and habitat fragmentation are also important factors rapidly altering the composition of communities in Mediterranean ecosystems (Linares et al. 2010; Olano et al. 2012; Matesanz et al. 2015). Therefore, a full understanding of the level of tolerance to climate change is particularly needed in such humanized Mediterranean habitats to forecast population trends and distribution of threatened tree species.

Changes in temperature and water availability often have marked effects on tree growth (Schweingruber 1996). Because trees are long-lived organisms, their ring series record long-term year-to-year changes in climate conditions (Schweingruber 1996; Nicault et al. 2008; Olano et al. 2008, 2012). Due to their complex physiology, trees may respond to climatic changes in complex ways (Drew et al. 2013; Olano et al. 2014; Zang et al. 2014). Moreover, changes in the constraining factors may cause temporal instability in the relationship between climate and tree growth that modulates the response patterns of tree growth (Briffa et al. 1998, 2002; D’Arrigo et al. 2008; Briffa and Matthews 2002; Leburgeois et al. 2012).

In the thermo-Mediterranean zone (i.e., altitude below $700 \mathrm{~m}$; Olson et al. 2001) climate imposes a double adversity for growth and survival of shrubs and trees, i.e., extreme summer droughts and erratic, unpredictable rain (Valladares et al. 2014). Global climate change is generally resulting in higher temperatures and lower precipitation, though such changes are not distributed uniformly throughout the year. As a consequence, the effect of climate change on tree-ring formation can vary depending on the relative importance of the two main limiting climate factors, making predictions particularly difficult. At higher altitudes, e.g., meso-, supra-, and oro-Mediterrranean zones (700-2700 m; Olson et al. 2001), where winter cold can be an important stressor, no agreed-upon trend in the response of tree growth to climate change has been inferred from long tree-ring series (Granda et al. 2013, 2014). Some studies have documented an increase (Martinez-Vilalta et al. 2008; Vila et al. 2008; Gimeno et al. 2012; Tegel et al. 2014), and others, a decrease in the growth of Mediterranean trees during the second half of the twentieth century (Jump et al. 2006; Saris et al. 2007; Piovesan et al. 2008; Di Filippo et al. 2010). Changes in climate-growth relationships have also been reported for several Mediterranean tree species (Andreu et al. 2007; Planells et al. 2009; Carrer et al. 2010; Leburgeois et al. 2012). However, the existing data are based mostly on widespread evergreen trees (e.g. Viera et al. 2009; Campelo et al. 2010; MartinBenito et al. 2011, 2013; Candel-Perez et al. 2012; Gimeno et al. 2012), and deciduous species have been much less studied in the Mediterranean area (e.g., Tegel et al. 2014; González-González et al. 2015). Even less is known about the response to climate change of small trees and shrubs at low altitudes in the thermo-Mediterranean.

In this study, we examined long-term changes in the stability of the climate-growth relationship of a thermoMediterranean deciduous small tree, to gain a perspective on the future persistence of this species, which has been decimated by different components of global change. Our model plant, the Iberian pear (Pyrus bourgaeana Decne), is a characteristic species of Mediterranean ecosystems and is considered important to their functioning (Cabezudo and Pérez Latorre 2004; Fedriani et al. 2010; Arenas-Castro et al. 2013). In Doñana National Park (SW Spain), P. bourgaeana trees often occur at low density in small scrubland patches among farmland, towns, and other built-over areas (Fedriani et al. 2010). Currently, P. bourgaeana shows a very low level of natural regeneration, most likely because of dispersal limitation, extreme summer droughts, and increased herbivore pressure, limiting seedling establishment (Fedriani et al. 2010, 2015). It is unclear whether and how mature $P$. bourgaeana tree growth has been affected by long-term changes in climate through the last century. This should be a fundamental step to predict the fate of the species, and, in general, of other deciduous thermo- and meso-Mediterranean shrubs and small trees, under a scenario of global warming. Specifically, in this study, we sought to answer the following two questions: (1) what sort of long-term climate-growth relationship is shown by $P$. bourgaeana?, and (2) is this relationship temporally stable, and if not, what is the trend of such/these changes, (if found any)?

\section{Methods}

\section{Study site}

The study site is located in southwestern Spain, in the Doñana World Biosphere Reserve $\left(37^{\circ} 9^{\prime} \mathrm{N}, 6^{\circ} 26^{\prime} \mathrm{W}\right.$; 0-80 $\mathrm{m}$ a.s.1.) on the west bank of the Guadalquivir River estuary. The Doñana area comprises three main ecosystems: mobile dunes, scrubland (where $P$. bourgaeana grows), and marshes. In the tree layer, in addition to our focal species, there are scattered Quercus suber, Olea europaea var. sylvestris, Fraxinus angustifolia, and Pinus pinea. In the understory, there are Pistacia lentiscus, Halimium halimifolium, Ulex spp., Chamaerops humilis, and Erica sp. (Valverde 1958; Fedriani et al. 1998, 2010). $P$. bourgaeana trees occur at low densities (generally less than one individual per ha; Fedriani et al. 2010) in patches of Mediterranean scrubland that are isolated from each other by natural or anthropogenic barriers (marshes, sand 
dunes or cultivations) (see also Żywiec et al. 2012 for details).

\section{Climate data}

Climate data were obtained from the Spanish Agencia Estatal de Metereología (AEMET) meteorological station located in Sevilla, the closest (ca. $80 \mathrm{~km}$ away) meteorological station providing long-term data and located near sea level (11 $\mathrm{m}$ a.s.l). Continuous data for daily mean temperature and daily total precipitation were available since 1946. We calculated mean temperature and accumulated precipitation for each month, as well as annual accumulated precipitation. Annual accumulated precipitation was summed from the September of the previous year to the August of the current year.

The climate is Mediterranean sub-humid, and is characterized by dry, hot, long summers (June-September) and mild, wet winters (November-February). In the study period (from 1946 to 2007), mean annual temperature varied considerably (Fig. 1a). The highest temperatures were recorded at the beginning and at the end of our studied period. The lowest temperatures occurred in the early 1970s and then increased consistently until the first decade of the twentyfirst century. Total annual precipitation also varied markedly, but no conspicuous temporal trend was found (Fig. 1a;
$\left.R^{2}=0.003, F_{1,59}=1.20, P=0.28\right)$. Groundwater availability shows marked seasonal changes in this area (Instituto Tecnologico Geominero Español, 1992). Precipitation is highest in the winter and lowest in the summer. The distribution of precipitation in a year changed along a studied period. The precipitation of January, February and March decreased considerably and the precipitation of October, November and December increased in the second half of the period considered in the study (Fig. 1b).

\section{Study species}

Pyrus bourgaeana Decne (Rosaceae) is a broadleaved deciduous tree. It is native to the Iberian Peninsula (Spain, Portugal) and North Africa (Morocco) (Aldasoro et al. 1996). It typically reaches 3-6 m height. Budburst occurs from February to April, and leaf senescence from June to September (Mediavilla and Escudero 2003; Arenas-Castro 2012). It flowers during February-March, is hermaphrodite and self-incompatible (Żywiec et al. 2012; Authors, unpublished data). In Doñana, annually, each $P$. bourgaeana tree typically produces between 200 and 450 fleshy fruits which ripen during the autumn (September-November; Fedriani et al. 2015). The fruits are non-dehiscent globose pomes (2-3 cm diameter) weighing ca. $6.7 \mathrm{~g}$, with sugary, juicy pulp (Fedriani et al. 2012).
Fig. 1 a Mean annual temperature (1946-2007) and total annual precipitation (1946-2007) near the study area; data from Sevilla weather station and b Climate diagrams for the meteorological station in Sevilla $\left(37^{\circ} 23^{\prime} 10^{\prime \prime} \mathrm{N}\right.$,

$5^{\circ} 59^{\prime} 33^{\prime \prime} \mathrm{W}, 11 \mathrm{~m}$ a. s. 1.) for the periods 1946-1976 and 1977-2007 indicating the intraannual distribution of monthly mean temperatures (line) and monthly total precipitation (bars); MAT mean annual temperature $\left({ }^{\circ} \mathrm{C}\right)$ and $M A P$ mean annual precipitation $[\mathrm{mm}]$
A

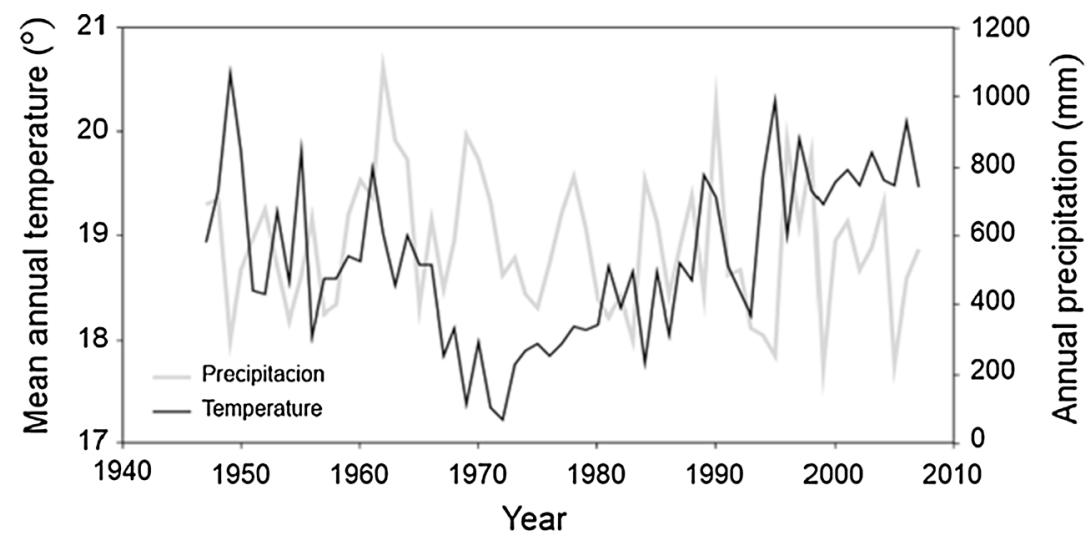

B

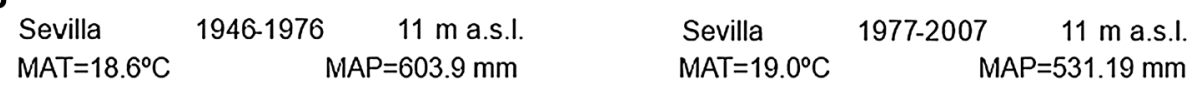

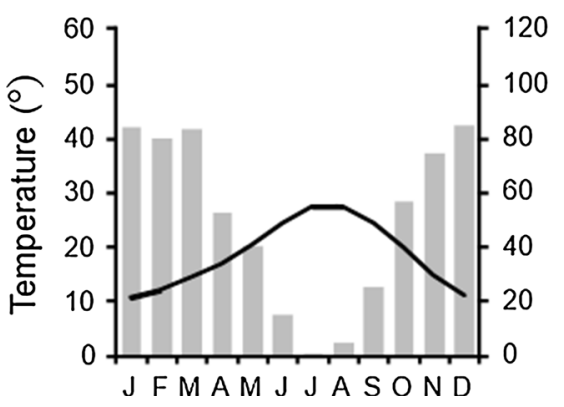


The Doñana population of $P$. bourgaeana has limited reproduction and regeneration ability (Fedriani and Delibes 2009; Fedriani et al. 2010, 2012). Our unpublished data indicate that the Doñana population of this long-lived tree shows a marked left-skewed demographic structure, with many individuals in older age classes, few juveniles, and even fewer seedlings and saplings. Despite the sparseness of this population, $P$. bourgaeana fruit, seeds, seedlings, and leaves represent important resources for diverse animal guilds, especially during the dry summers (e.g., Fedriani and Delibes 2009; Fedriani et al. 2012); so, its persistence is critical to the ecological stability of the community.

\section{Data collection}

Trees $(n=32)$ were sampled in winter and spring of 2008 and 2009. Tree clusters grow scattered in Mediterranean scrubland, in similar light conditions representing the uppermost vegetation layer. Their mean diameter (dbh) was $18 \mathrm{~cm}( \pm 11)$. The trees were cored with an increment borer (diameter $5 \mathrm{~mm}$ ) ca. $40 \mathrm{~cm}$ above the tree base. The cores were glued to wood slats, dried and polished with a belt sander (progressively up to grid 600) to make the treering sequences clearly visible. The samples were scanned at 2400 dpi resolution. WinDENDRO (http://www.regentin struments.com/assets/windendro_about.html) was used to measure the annual tree-ring widths to $0.01 \mathrm{~mm}$ accuracy. Core sections with extremely narrow, missing or false rings were carefully checked under a stereomicroscope at $7-45 \times$. The quality of dating was checked with the CoFECHA program (Dendrochronology Program Library, Holmes and Cook 1983). All measurement series with potential errors were re-checked once again and corrected if dating errors were found (Holmes et al. 1986).

\section{Data analysis}

\section{Tree-ring chronology}

We calculated the index series to study the influence of climate factors on tree growth (Holmes 1994). Individual raw ring-width series were standardized using ARSTAN software by fitting a horizontal line through the mean values of the series, and, in the next step, by dividing the measurement in every year by the mean value calculated for each series (Holmes 1994). Then, we performed autoregressive modeling of the index series to remove autocorrelations and enhance the common signal of the trees. After that, the indices of individual trees were averaged to an indexed chronology by applying a biweight robust mean (Holmes 1994). The first-order autocorrelation of the 1904-2007 raw chronology (a measure of the lagged effect of ring width from the previous year on next-season growth) was 0.455 , and the first-order autocorrelation of the indexed chronology was -0.137 . This means that a great part of the autocorrelation was removed in the process of constructing the indexed chronology allowing dendroclimatological analyses.

Mean sensitivity, expressing the interannual variability of ring width, was calculated for the indexed chronology 1947-2007 (Fritts 1976). For the period 1947-2007, we also calculated the expressed population signal (EPS), which quantifies how well a chronology based on a finite number of trees represents the hypothetical perfect or true chronology (Wigley et al. 1984).

Weather factors influencing tree growth and temporal changes in the climate-growth relationship

The indexed chronology was used for calculation of the tree growth-climate relationship. To evaluate the potential relationship between tree growth and annual precipitation, we performed several simple regression analyses, first regressing the indexed chronology and year, and then, annual precipitation and year. Then, we used the residuals from those two previous analyses and regressed them to evaluate their potential relationship once the effect of year was corrected for (e.g., Ovaskainen et al. 2013).

The relationships between tree growth and monthly climatic conditions (mean monthly temperature, total monthly precipitation) were calculated through correlation and response function analyses with DendroClim2002 (Biondi and Waikul 2004). The program applies a bootstrap process to assess the statistical significance of the correlations.

Time-dependent changes in the relationship between tree growth and climate factors were analyzed using DendroClim2002 as well. The correlations of indexed chronology with total monthly precipitation and mean monthly temperature (from previous September to current June) were done for 30-year periods. The moving correlation windows (32 periods) were progressively shifted by 1 year over time at each iteration (the first for 1947-1976 and the last for 1978-2007). Moreover, for each 30-year period, climatic conditions were defined as mean monthly precipitation and mean monthly temperature.

\section{Results}

\section{Patterns of tree growth}

The constructed indexed chronology (based on $32 P$. bourgaeana trees) covers a 103-year time span (1905-2007; Fig. 2a, b). The two oldest trees had 104 rings (at ca. $40 \mathrm{~cm}$ height). Mean ring width was $1.34 \mathrm{~mm}$ 
$( \pm 1.04)$ for 1947-2007, and $1.35 \mathrm{~mm}( \pm 1.04)$ for 1904-2007; it reached maximum of $7.83 \mathrm{~mm}$ in 1996 as calculated from the raw chronology. The mean sensitivity of the indexed chronology for 1947-2007 was 0.49. The expressed population signal (EPS) for 1947-2007 was 0.87. With time, the number of years for which the tree series showed no ring formation (missing ring) increased: in the 1950s and 1960s, there were no absent rings; in the 1970s, 1 year had no ring (1974; 2 trees); in the 1980s, there were 4 such years $(1980,1981,1983,1989 ; 1$ tree each year); in the 1990s, there were 5 such years (1992-1995 and 1999;1-3 trees each year); and in the first 7 years of the twenty-first century, there was 1 year with a missing ring (2005; 1 tree).

\section{Long-term climate-growth relationship}

Tree growth was strongly and positively related to annual precipitation, summed from September of the previous year to August of the current year (Fig. 2b; regression of residuals: $R^{2}=0.66, \quad F_{1,59}=114.25, \quad P<10^{-4}$ ). Tree growth was not correlated with total precipitation of the preceding year (regression of residuals: $R^{2}=0.01$, $\left.F_{1,58}=0.28, P=0.60\right)$. Correlation coefficients showed that precipitation from November of the previous year to January of the current year was especially important for tree growth (Fig. 3). Almost the same was found using response function coefficients; precipitation of previous October, previous November, and January and February of the current year positively affected growth (Fig. 3). Precipitation from February to June of the current year also positively influenced growth, with June precipitation being the most important among those months (Fig. 3).

Mean monthly temperature influenced tree growth less than precipitation did (Fig. 3). There was a positive correlation between tree growth and temperature of the previous October. High winter temperature (previous December and current January) also influenced growth positively, but this relationship was significant only for current January temperature. High temperature from April
Fig. 2 Row chronology of $P$. bourgaeana in the Doñana area with number of measured trees (a) and indexed chronology with annual precipitation records from the Sevilla weather station (b)
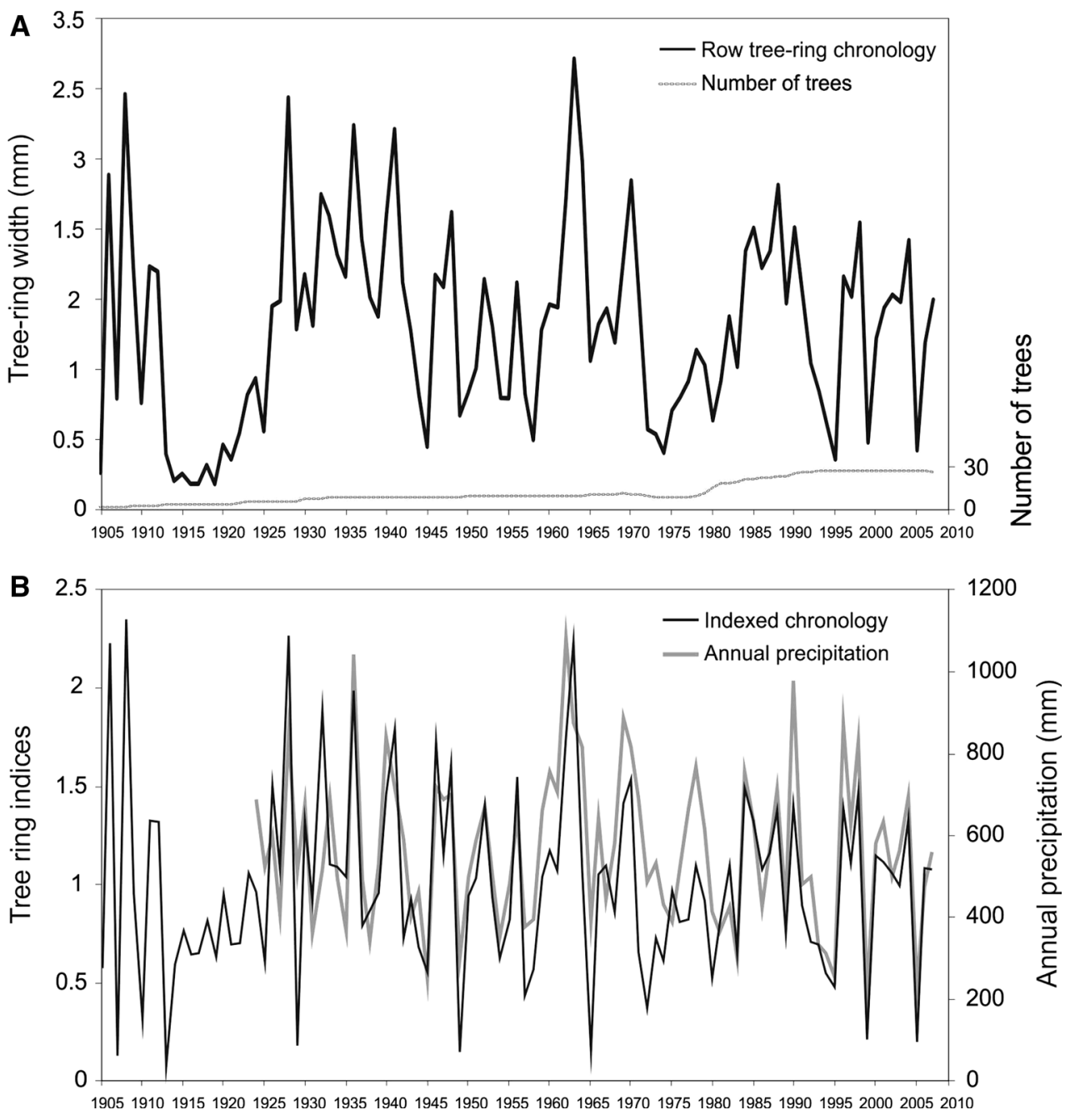

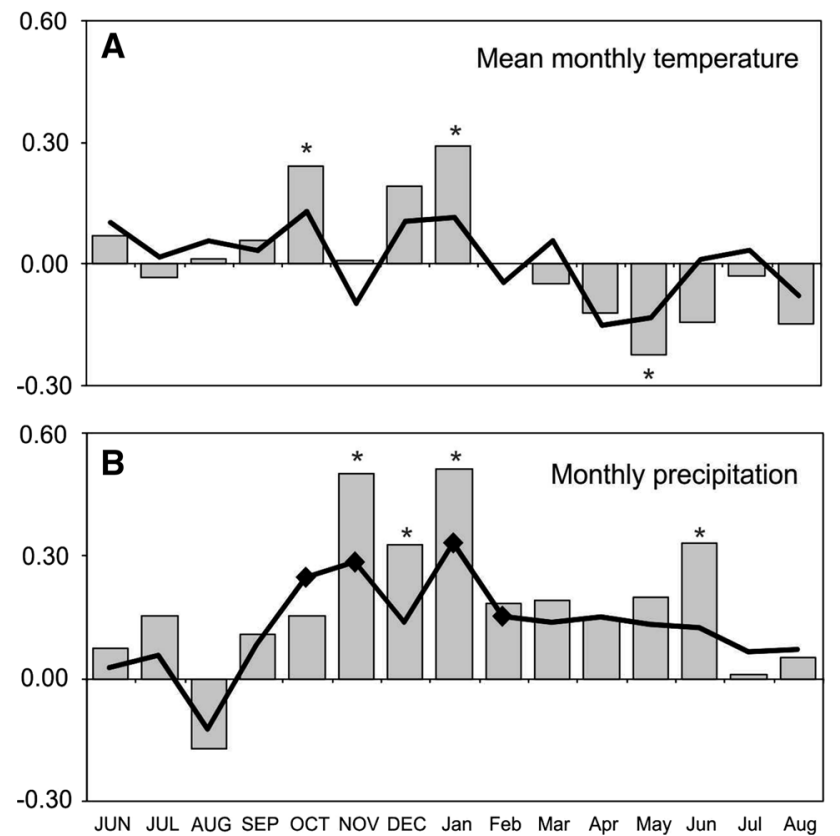

Fig. 3 Bootstrap correlations (bars) and response (line) calculated between the indexed chronology of $P$. bourgaeana and monthly mean temperature (a) and sum of monthly precipitation (b) from previous June (JUN) to current August (Aug) in 1947-2007; asterisks (correlation) and marks (response) indicate significance at $95 \%$ confidence level

to June of the current year negatively influenced tree-ring formation, but this relationship was significant only for May (Fig. 3). Response function coefficients between monthly temperatures and growth were not significant in any month, although they showed similar trends as for the correlation functions (Fig. 3).

\section{Changes in the climate-growth relationship}

The relationship between tree growth and total annual precipitation was always positive and strong during the whole analyzed period (1947-2007; Fig. 4). The influence of annual precipitation becomes more important for tree growth in the late twentieth and early twenty-first centuries, when annual precipitation decreased and it probably became most limiting. For total monthly precipitation, during the whole analyzed period, there was a strong positive relationship between tree growth and precipitation in the previous November and current January (Fig. 5). The relationship between total monthly precipitation of the previous December and tree growth strengthened beginning in the 1960s (Fig. 5). The relationship between precipitation in the spring and tree growth fluctuated and was rather weak in the studied period (Fig. 5). The positive relationship between growth and total precipitation in the vegetative period was strongest for June, but it decreased in the late twentieth and early twenty-first centuries (Fig. 5).
The positive relationship between tree growth and mean temperature in autumn and winter (from previous October to December) strengthened in the second half of the studied period, coinciding with an increasing mean temperature trend; we found the same trend for February (Fig. 5). There was no time trend in the relationship between tree growth and mean spring temperature, despite the increase of temperature in the last few decades (Fig. 5).

\section{Discussion}

In this study, we made the first dendroclimatological analyses of the thermo-Mediterranean tree $P$. bourgaeana and constructed a first 103-year tree-ring chronology of this species. Recently, Arenas-Castro et al. (2015) described average increase in basal area per year and age structure based on $P$. bourgaeana tree-rings. This small deciduous tree grows in the thermo-Mediterranean zone, where winter is relatively mild, and thus, tree responses to climate change could deviate from those observed at higher Mediterranean altitudes. We found a strong relationship between tree growth and climate, with annual precipitation being the most important limiting factor for $P$. bourgaeana radial growth. We showed that in recent decades, the relationship between growth and climate has strengthened. The increasing number of years with absent rings suggests that climatic conditions for this species worsened toward the end of the twentieth century. In combination with habitat destruction and fragmentation in the Doñana area, and in the Mediterranean in general, it indicates that our study species is seriously threatened by a myriad of contrasting factors.

\section{Tree growth and its long-term relationship with climate}

The high sensitivity of $P$. bourgaeana, as expressed in large year-to-year variation of ring width, might have been partly related to the species's low stomatal sensitivity to atmospheric drought (Mediavilla and Escudero 2003). The high sensitivity is typical for trees growing in environments with a strong, temporally variable limiting factor (Holmes et al. 1986). P. bourgaeana mean sensitivity (0.49) was close to values found for the small-sized Pinus edulis (0.58) growing at extremely dry sites in Arizona (Fritts et al. 1965), but much higher than most values reported recently for large-sized tree species growing in the Mediterranean area at higher altitudes, such as Pinus sylvestris, P. nigra, Abies alba, and Fagus sylvatica (range 0.19-0.35; Leburgeois et al. 2012; Martin-Benito et al. 2013; Andreu et al. 2007; Cailleret and Davi 2011; Piovesan et al. 2008). 
Fig. 4 Bootstrap correlations (black line) of $P$. bourgaeana indexed chronology with total annual precipitation. Bootstrap correlations were calculated for 30 -year periods lagged year-byyear through 1947-2007 (from 1947-1976 to 1978-2007).

Grey dashed line is trend of mean annual precipitation over the 32 30-year periods

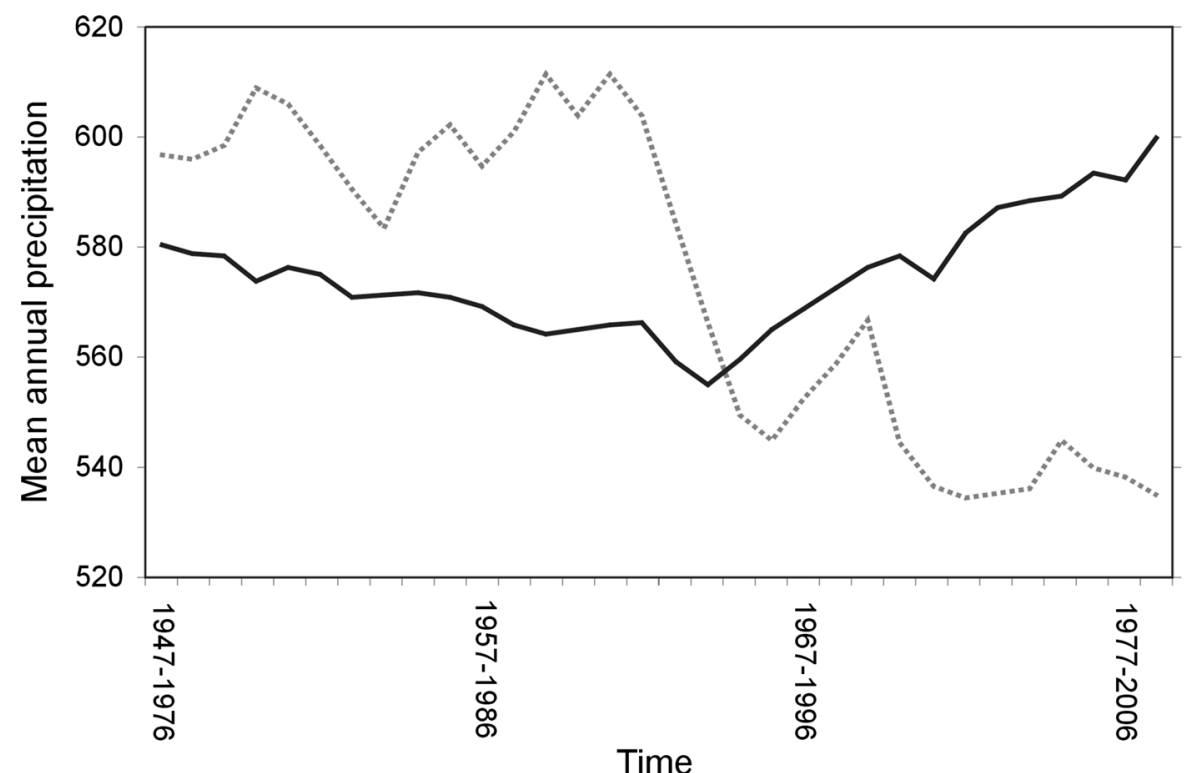

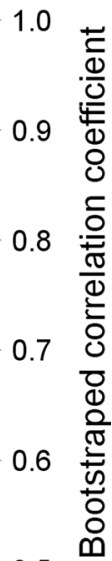

Time

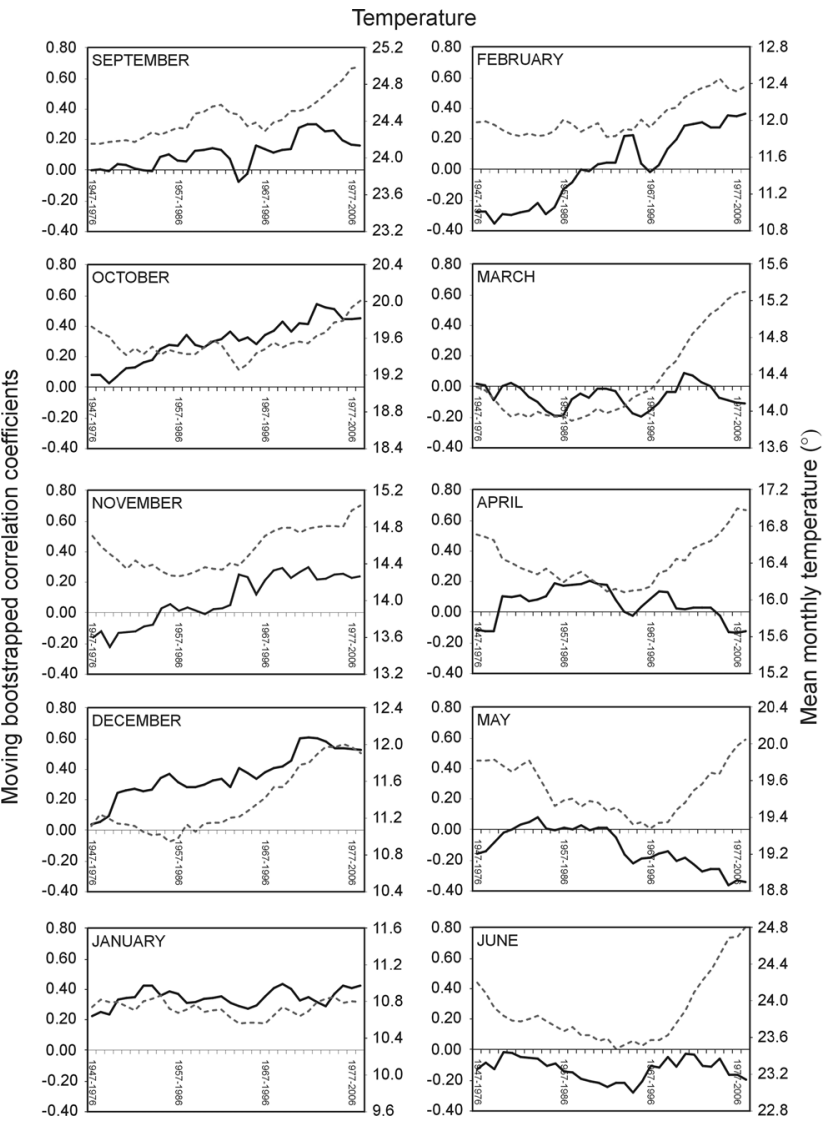

Fig. 5 Moving bootstrap correlations (black line) of P. bourgaeana indexed chronology with total monthly precipitation and mean monthly temperature (from previous September to current June) in 1947-2007. Bootstrap correlations were calculated for 30-year

Drought is a primary growth-limiting factor of Mediterranean tree species, especially at low altitudes (Thompson 2005; Vicente-Serrano et al. 2010, 2012;

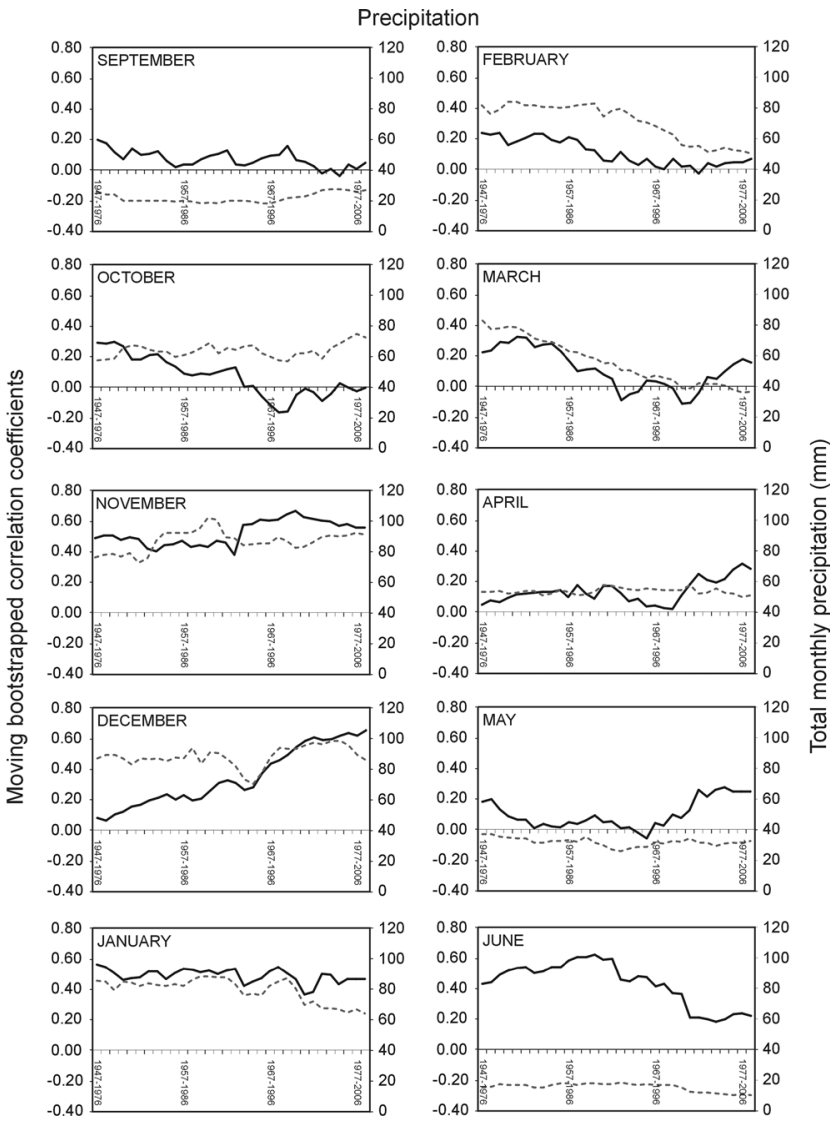

periods lagged year-by-year through 1947-2007 (from 1947-1976 to 1978-2007). Grey dashed line is trend of total monthly precipitation and mean monthly temperature over the 32 30-year periods

Pugnaire and Valladares 2007; Olano et al. 2014). However, previous dendroclimatological studies of a number of tree and shrub species at relatively high altitudes show that 
tree-ring chronologies are not always strongly correlated with annual precipitation (Cherubini et al. 2003; Gimeno et al. 2012; but see Gutiérrez et al. 2011; Martin-Benito et al. 2011; Granda et al. 2013). In our thermo-Mediterranean study, $P$. bourgaeana showed a very strong positive relationship between total annual precipitation and radial growth.

Previous autumn and winter precipitation is known to boost tree-ring formation in several Mediterranean species (e.g., Campelo et al. 2006, 2010; Di Filippo et al. 2010). The highest precipitation in this region occurs in winter or autumn, and this time is responsible for soil water recharge (Instituto Tecnologico Geominero Español 1992). However, maximum tree growth occurs in the spring (Cherubini et al. 2003). In the study area, precipitation was relatively high from November to January, and its year-to-year variation was lower in these months than during the rest of the year. Precipitation in the spring months of the growth season was much more variable, and trended downward over the course of the studied period. In the Doñana area, water accumulated in the ground during autumn and winter, when $P$. bourgaeana trees are dormant, seems to be a key factor influencing their growth in the following vegetative period. It establishes an essential resource for initiation of cambial activity and production of early wood (Granda et al. 2013; Martin-Benito et al. 2013).

Temperature limits tree growth in some Mediterranean ecosystems, though less than precipitation does (Cherubini et al. 2003). The limiting effect of winter cold has been observed mainly for evergreen species (Martin-Benito et al. 2011, 2013; Granda et al. 2013) and for trees growing in mountain conditions (Leburgeois et al. 2012; Martin-Benito et al. 2013). Our results in a warmer thermo-Mediterranean site show that a warm previous autumn and winter positively affect growth of the deciduous species growing at low elevation. Two mechanisms might explain such a relationship in $P$. bourgaeana. First, high autumn temperatures can increase the quality, size and survival of buds formed for the next year, and, thus, the assimilation ability of the plant in the following season (Weber et al. 2007). Second, a warm end of winter can accelerate cambial reactivation after winter dormancy and earlier leaf burst, thereby prolonging the growing season and the period of wood formation (Leburgeois et al. 2012; Rötzer et al. 2004; Sanz-Pérez et al. 2009; Cailleret and Davi 2011; Viera et al. 2014). On the other hand, higher temperatures in spring and early summer slightly reduced the growth of $P$. bourgaeana. In water-limited regions, high temperatures can cause water stress and the trees usually respond by reducing their stomatal conductance to avoid water loss (Baquedano and Castillo 2007) or, in the case of P. bourgaeana, by early leaf abscission in the summer (Mediavilla and Escudero 2003).

\section{Changes in the climate-growth relationship}

Climatic changes have led to temporal instability of climate-growth relationships in the Mediterranean region (Andreu et al. 2007; Planells et al. 2009; Carrer et al. 2010) and elsewhere (Briffa et al. 1998). Generally, our results showed no temporal stability in the relationship between tree growth and climate from 1947 to 2007. The most general temporal trend was the relationship between annual precipitation and tree growth. The decrease of rainfall in the last decades of the twentieth century caused a steady rise of that correlation, reaching high values. This relationship was very strong during the whole period studied, but its strengthening through time makes it clear that lower precipitation during the last decades has limited the growth of $P$. bourgaeana more than it did earlier. Similar longterm patterns have been reported from other species living at higher altitudes, e.g., Fagus sylvatica (Piovesan et al. 2008) and for Pinus sylvestris (Planells et al. 2009; Andreu-Hayles et al. 2011).

The distribution of rainfall over the year is the most essential element of the precipitation-growth relationship. The most stable and strongest relationship was found between growth and total monthly precipitation in the previous November and January. Spring drought is considered a primary growth-limiting factor in the high-altitude Mediterranean areas (Leburgeois et al. 2012; Cherubini et al. 2003). Surprisingly, during some spring months, the relationship between $P$. bourgaeana growth and precipitation was stronger at the beginning of the studied period, when mean precipitation was higher, and almost disappeared in the late twentieth and early twenty-first centuries, when precipitation was lower. This suggests that high precipitation in the spring boosts $P$. bourgaeana growth, but that lower precipitation at that time does not limit growth so much, as it depends mostly on autumn and winter precipitation. On the other hand, the relationship between June precipitation and growth decreased strongly over time even though June precipitation was very low throughout the studied period what can be the result of the changed tree phenology.

In the twentieth century, directional changes in the temperature-growth relationship have been reported by other researchers (Andreu et al. 2007; Planells et al. 2009). Our data show that the positive relationship between autumn and winter temperature and tree growth became stronger at the end of the twentieth century, coincident with the increasing trend of temperature in this period. It seems that winter warming initiated a positive growth response to temperature. Leburgeois et al. $(2010,2012)$ found that spring warming strengthened the positive growth response to temperature in several species. In our study, the positive 
relationship between mean February temperature and tree growth started when temperature during this month increased. This suggests that at higher February temperature, the growth of $P$. bourgaeana begins earlier, extending the vegetative period.

Our investigation indicates that the growth of mature $P$. bourgaeana in Doñana was limited by climatic conditions during the whole studied period, and that the climate-growth relationship was more pronounced in the late twentieth and early twenty-first centuries as climate became more arid. There was a clearly stronger relationship between precipitation and tree growth at the end of the twentieth century, when the number of missing rings also increased. However, the negative influence of climate change was not as strong as might be expected. A recent review of results on current effects of climate change on Mediterranean forests reached a similar conclusion (Valladares et al. 2014). As for any other tree species, however, the persistence of $P$. bourgaeana in Doñana depends not only on the vigor and health of existing mature trees, but also on recruitment (Fedriani et al. 2012). Though adult trees might somewhat tolerate climate change, the current scarcity of young $P$. bourgaeana plants (seedlings, saplings; our unpublished data) appears to pose a serious threat to this population. Further similar analyses of other thermo-Mediterranean tree and shrub species growing in such particularly stressful conditions are needed to achieve a better understanding of the response of plants to climate change in humanized landscapes.

Author contribution statement M.Ż., J.M.F. and M.D. conceived the ideas; M.Ż., E.M., T.Z. and G.C. collected the data; E.M., M.Ż, and T.Z. analysed the data; and M.Z., E.M. and J.M.F. led the writing.

Acknowledgments We are indebted with many volunteers and students who provided essential field assistance. Jose Miguel Olano made numerous useful comments that improved a previous draft. The Spanish Ministerio de Educación y Ciencia (CGL2007-63488/BOS) supported this study. The Spanish Agencia Estatal de Metereología (AEMET) kindly provided climate data (ref. 990140100). The statutory fund of the Institute of Botany of the Polish Academy of Sciences also provided partial funding.

\section{Compliance with ethical standards}

Conflict of interest The authors declare that they have no conflict of interest.

Open Access This article is distributed under the terms of the Creative Commons Attribution 4.0 International License (http://crea tivecommons.org/licenses/by/4.0/), which permits unrestricted use, distribution, and reproduction in any medium, provided you give appropriate credit to the original author(s) and the source, provide a link to the Creative Commons license, and indicate if changes were made.

\section{References}

Aldasoro JJ, Aedo C, Muñoz-Garmendia F (1996) The genus Pyrus L. (Rosaceae) in south-west Europe and North Africa. Biol J Linn Soc 121:143-158

Allen CD, Macalady AK, Chenchouni H et al (2010) A global overview of drought and heat-induced tree mortality reveals emerging climate change risks for forests. For Ecol Manage 259:660-684

Anderegg WRL, Kane JM, Anderegg LDL (2013) Consequences of widespread tree mortality triggered by drought and temperature stress. Nat Clim Change 3:30-36

Andreu L, Gutiérrez E, Macias M, Ribas Bosch O, Camarero JJ (2007) Climate increases regional tree-growth variability in Iberian pine forests. Glob Change Biol 13:1-12

Andreu-Hayles L, Planells O, Guriérrez E, Muntan E, Helle G, Anchukaitis K, Schleser G (2011) Long tree-ring chronologies reveal 20th century increases in water-use efficiency but no enhancement of tree growth at five Iberian pine forests. Glob Change Biol 17:2095-2112

Arenas-Castro S (2012) Análisis de la estructura de una población de Piruétano (Pyrus bourgaeana) basado en técnicas de eledetección y SIG. Tesis de Doctorado, Universidad de Córdoba, Espana. http://hdl.handle.net/10396/7832

Arenas-Castro S, Julien Y, Jiménez-Munoz JC, Sobrino JA, Fernández-Haeger J, Jordano-Barbudo D (2013) Mapping wild pear trees (Pyrus bourgaeana) in Mediterranean forest using high-resolution QuickBird satellite imagery. Int J Remote Sens 34:3376-3396

Arenas-Castro S, Fernández-Haeger J, Jordano-Barbudo D (2015) Estructura de edades, tamańos y crecimiento en una población local de piruétano (Córdoba, Espańa). Ecosistemas 24(2):7-14

Baquedano FJ, Castillo FJ (2007) Drought tolerance in the Mediterranean species Quercus coccifera, Quercus ilex, Pinus halepensis, and Juniperus phoenicea. Photosynthetica 45(2):229-238

Barbeta A, Ogaya R, Peńuelas J (2013) Dampening effects of longterm experimental drought on growth and mortality rates of a Holm oak forest. Glob Change Biol 19:3133-3144

Biondi F, Waikul K (2004) DENDROCLIM2002: a C++ program for statistical calibration of climate signals in tree-ring chronologies. Comput Geosci 30:303-311

Briffa KR, Matthews JA (2002) ADVANCE-10 K: a European contribution towards a hemispheric dendroclimatology for the Holocene. Holocene 12:639-642

Briffa KR, Schweingruber FH, Jones PD et al (1998) Trees tell of past climates: but are they speaking less clearly today? Philos Trans R Soc Lond B 353:65-73

Briffa KR, Osborn TJ, Schweingruber FH, Jones PD, Shiyatov SG, Vaganov EA (2002) Tree-ring width and density data around the Northern Hemisphere: part 2, spatio-temporal variability and associated climate patterns. Holocene 12:759-789

Cabezudo B, Pérez Latorre B (2004) Las comunidades vegetales. En: Herrera, C. M. (Coordinador). El monte mediterráneo en Andalucía. Consejería de Medio Ambiente, Junta de Andalucía, Sevilla, Espana

Cailleret M, Davi H (2011) Effects of climate on diameter growth of co-occurring Fagus sylvatica and Abies alba along an altitudinal gradient. Trees 25:265-276

Campelo F, Nabais C, Freitas H, Gutiérrez E (2006) Climatic significance of tree-ring width and intra-annual density fluctuations in Pinus pinea from a dry Mediterranean area in Portugal. Ann For Sci 64:229-238

Campelo F, Nabais C, Gutiérrez E, Freitas H, García-González I (2010) Vessel features of Quercus ilex L. growing under 
Mediterranean climate have a better climatic signal than treering width. Trees 24:463-470

Candel-Perez D, Linares JC, Vińegla B, Lucas-Borja ME (2012) Assessing climate-growth relationships under contrasting stands of co-occurring Iberian pines along an altitudinal gradient. For Ecol Manage 274:48-57

Carrer M, Nola P, Motta R, Urbinati C (2010) Contrasting tree-ring growth to climate responses of Abies alba toward the southern limit of its distribution area. Oikos 119:1515-1525

Cherubini P, Gartner BL, Tognetti R, Bräker OU, Schoch W, Innes JL (2003) Identifcation, measurement and interpretation of tree rings in woody species from mediterranean climates. Biol Rev 78:119-148

D'Arrigo R, Wilson R, Liepert B, Cherubini P (2008) On the 'Divergence Problem' in Northern Forests: a review of the tree-ring evidence and possible causes. Glob Planet Change 60:289-305

Di Filippo A, Alfredo Alessandrini A, Biondi F, Blasi S, Portoghesi L, Piovesan G (2010) Climate change and oak growth decline: dendroecology and stand productivity of a Turkey oak (Quercus cerris L.) old stored coppice in Central Italy. Ann For Sci 67:706

Drew DM, Allen K, Downes GM, Evans R, Battaglia M, Baker P (2013) Wood properties in a long-lived conifer reveal strong climate signals where ring-width series do not. Tree Physiol 33:37-47

Fedriani JM, Delibes M (2009) Seed dispersal in the Iberian pear Pyrus bourgaeana: a role for infrequent mutualists. Ecoscience 16:211-221

Fedriani JM, Wiegand T, Delibes T (2010) Spatial patterns of adult trees and the mammal-generated seed rain in the Iberian pear. Ecography 33:545-555

Fedriani JM, Żywiec M, Delibes M (2012) Thieves or mutualists? Pulp feeders enhance endozoochore local recruitment. Ecology 93(3):575-587

Fedriani JM, Wiegand T, Calvo G, Suárez-Esteban A, Jácome M, Żywiec M, Delibes M (2015) Unravelling density and distance dependence of plant reproduction using a spatially-explicit framework. J Ecol 103:1344-1353

Fischer EM, Schär C (2010) Consistent geographical patterns of changes in high-impact European heatwaves. Nat Geosci 3:398-403

Fritts HC (1976) Tree Rings and Climate. Academic Press, New York, p 567

Fritts HC, Smith DG, Cardis JW, Budelsky CA (1965) Tree-ring characteristics along a vegetation gradient in northern Arizona. Ecology 46:393-401

Gimeno TE, Camarero JJ, Granda E, Pías B, Valladare F (2012) Enhanced growth of Juniperus thurifera under a warmer climate is explained by a positive carbon gain under cold and drought. Tree Physiol 32:326-336

González-González BD, Vázquez-Ruiz RA, García-González I (2015) Effects of climate on earlywood vessel formation of Quercus robur L. and $Q$. pyrenaica Willd. at a site in the northwestern Iberian Peninsula. Can J For Res 45(6):698-709

Granda E, Camarero JJ, Gimeno T, Martínez-Fernández J, Valladares F (2013) Intensity and timing of warming and drought differentially affect growth patterns of co-occurring Mediterranean tree species. Eur J For Res 132:469-480

Granda E, Rossatto DR, Camarero JJ, Voltas J, Valladares F (2014) Growth and carbon isotopes of Mediterranean trees reveal contrasting responses to increased carbon dioxide and drought. Oecologia 174:307-317

Gutiérrez E, Campelo F, Camarero JJ, Ribas M, Muntán E, Nabais Nabais C, Freitas H (2011) Climate controls act at different scales on the seasonal pattern of Quercus ilex L. stem radial increments in NE Spain. Trees 25:637-646
Hoerling M, Eischeid J, Perlwitz J, Quan X, Zhang T, Pegion P (2012) On the increased frequency of Mediterranean drought. J Clim 25:2146-2161

Holmes RL (1994) Dendrochronology Program Library - Users Manual. Laboratory of Tree-Ring Research, University of Arizona, Tucson

Holmes RL, Cook ER (1983) Computer-assisted quality control in tree-ring dating and measurement. Tree-Ring Bull 43:69-75

Holmes RL, Adams RK, Fritts HC (1986) Tree-ring chronologies of western North America: California, eastern Oregon and northern Great Basin. Laboratory of Tree-Ring Research, University of Arizona, Tucson

Instituto Tecnologico Geominero Español (1992) Hidrogeologia del Parque Nacional de Doñana y su entorno. Instituto Tecnologico Geominero Español, Madrid

IPCC (2014) Climate Change 2014: Synthesis Report. Contribution of Working Groups I, II and III to the Fifth Assessment Report of the Intergovernmental Panel on Climate Change. In: Core Writing Team, R.K. Pachauri and L.A. Meyer (eds.). IPCC, Geneva, Switzerland, p 151

Jump AS, Hunt JM, Peńuelas J (2006) Rapid climate change-related growth decline at the southern range edge of Fagus sylvatica. Glob Change Biol 12:2163-2174

Leburgeois F, Rathgeber CBK, Erwin Ulrich E (2010) Sensitivity of French temperate coniferous forests to climate variability and extreme events (Abies alba, Picea abies and Pinus sylvestris). J Veg Sci 21:364-376

Leburgeois F, Mérian P, Courdier F, Ladier J, Dreyfus P (2012) Instability of climate signal in tree-ring width in Mediterranean mountains: a multi-species analysis. Trees 26:715-729

Linares JC, Camarero JJ, Carreira JA (2010) Competition modulates the adaptation capacity of forests to climatic stress: insights from recent growth decline and death in relict stands of the Mediterranean fir Abies pinsapo. J Ecol 98:592-603

Luterbacher J, García-Herrera R, Akcer-On S et al (2012) A review of 2000 years of paleoclimatic evidence in the Mediterranean. In: Lionello P (ed) The climate of the mediterranean region: from the past to the future. Elsevier, Amsterdam, pp 87-185

Martin-Benito D, Kint V, del Río M, Muys B, Cańellas I (2011) Growth responses of West-Mediterranean Pinus nigra to climate change are modulated by competition and productivity: past trends and future perspectives. For Ecol Manage 262:1030-1040

Martin-Benito D, Beeckman H, Cańellas I (2013) Influence of drought on tree rings and tracheid features of Pinus nigra and Pinus sylvestris in a mesic Mediterranean forest. Eur J For Res 132:33-45

Martinez-Vilalta J, López BC, Adell L, Badiella L, Ninyerola M (2008) Twentieth century increase of Scots pine radial growth in NE Spain shows strong climate interactions. Glob Change Biol 14:2868-2881

Matesanz S, Gómez-Fernández A, Alcocer I, Escudero A (2015) Fragment size does not matter when you are well connected: effects of fragmentation on fitness of coexisting gypsophiles. Plant Biol 17(5):1047-1056

Mediavilla S, Escudero A (2003) Stomatal responses to drought at a Mediterranean site: a comparative study of co-occurring woody species differing in leaf longevity. Tree Physiol 23:987-996

Nicault A, Alleaume S, Brewer S, Carrer M, Nola P, Guiot J (2008) Mediterranean drought fluctuation during the last 500 years based on tree-ring data. Clim Dyn 31:227-245

Olano JM, Rozas V, Bartolomé D, Sanz D (2008) Effects of changes in traditional management on height and radial growth patterns in a Juniperus thurifera L. woodland. For Ecol Manage 255:506-512

Olano JM, Eugenio M, García-Cervigón AI, Folch M, Rozas V (2012) Quantitative tracheid anatomy reveals a complex environmental 
control of wood structure in continental Mediterranean climate. Int J Plant Sci 173:137-149

Olano JM, Linares JC, García-Cervigón AI, Arzac A, Delgado A, Rozas V (2014) Drought-induced increase in water-use efficiency reduces secondary tree growth and tracheid wall thickness in a Mediterranean conifer. Oecologia 176:273-283

Olson DM, Dinerstein E, Wikramanayake ED et al (2001) Terrestrial Ecoregions of the World: a New Map of Life on Earth A new global map of terrestrial ecoregions provides an innovative tool for conserving biodiversity. Bioscience 51(11):933-938

Ovaskainen O, Skorokhodova S, Yakovleva M et al (2013) Community-level phenological response to climate change. Proc Natl Acad Sci 110:13434-13439

Piovesan G, Biondi F, Di Filippo A, Alessandrini A, Maugeri O (2008) Drought-driven growth reduction in old beech (Fagus sylvatica L.) forests of the central Apennines, Italy. Global Change Biology 14:1-17

Planells O, Gutiérrez E, Helle G, Schleser GH (2009) A forced response to twentieth century climate conditions of two Spanish forests inferred from widths and stable isotopes of tree rings. Clim Change 97:229-252

Pugnaire FI, Valladares F (2007) Functional plant ecology. CRC Publishing, Boca Raton

Rötzer T, Grote R, Pretzsch H (2004) The timing of bud burst and its effect on tree growth. Int J Biometeorol 48:109-118

Sanz-Pérez V, Castro-Díez P, Valladares F (2009) Differential and interactive effects of temperature and photoperiod on budburst and carbon reserves in two co-occurring Mediterranean oaks. Plant Biol 11:142-151

Saris D, Christodoulakis D, Körner C (2007) Recent decline in precipitation and tree growth in the eastern Mediterranean. Glob Change Biol 13:1187-1200

Schweingruber FG (1996) Tree rings and environment. Dendroecology. Haupt, Bern, Switzerland

Tegel W, Seim A, Hakelberg D, Hoffmann S, Panev M, Westphal T, Büntgen U (2014) A recent growth increase of European beech (Fagus sylvatica L.) at its Mediterranean distribution limit contradicts drought stress. Eur J For Res 133:61-71

Thompson JN (2005) The geographic mosaic of coevolution. University of Chicago, Chicago
Valladares F, Benavides R, Rabasa SG, Díaz M, Pausas JG, Paula S, Simonson WD (2014) Global change and Mediterranean forests: current impacts and potential responses. In: David A. Coomes, David F. R. P., Burslem and William D. Simonson (eds.). Cambridge University, Cambridge, $\mathrm{p}$ 47-75

Valverde JA (1958) An ecological sketch of the Coto Doñana. Br Birds 51:1-23

Vicente-Serrano SM, Lasanta T, Gracia C (2010) Aridification determines changes in leaf activity in Pinus halepensis forests under semiarid Mediterranean climate conditions. Agric For Meteorol 150:614-628

Vicente-Serrano SM, Zouber A, Lasanta T, Pueyo Y (2012) Dryness is accelerating degradation of vulnerable shrublands in semiarid Mediterranean environments. Ecol Monogr 82(4):407-428

Viera J, Campelo F, Nabais C (2009) Age-dependent responses of tree-ring growth and intra-annual density fluctuations of Pinus pinaster to Mediterranean climate. Trees 23:257-265

Viera J, Rossi S, Campelo F, Freitas H, Nabais C (2014) Xylogenesis of Pinus pinaster under a Mediterranean climate. Ann For Sci 71:71-80

Vila B, Vennetier M, Ripert C, Chandioux O, Liang E, Guibal F, Torre F (2008) Has global change induced divergent trends in radial growth of Pinus sylvestris and Pinus halepensis at their bioclimatic limit? The example of the Sainte-Baume forest (south-east France). Ann For Sci 65:709

Weber P, Bugmann H, Rigling A (2007) Radial growth responses to drought of Pinus sylvestris and Quercus pubescens in an innerAlpine dry valley. J Veg Sci 18:777-792

Wigley TML, Briffa KR, Jones PD (1984) On the average value of correlated time series with applications in dendroclimatology and hydrometeorology. J Climate Appl Meteorol 23:201-213

Zang C, Hartl-Meier C, Dittmar C, Rothe A, Menzel A (2014) Patterns of drought tolerance in major European temperate forest trees: climatic drivers and levels of variability. Glob Change Biol 20:3767-3779

Żywiec M, Delibes M, Fedriani JM (2012) Microgeographical, interindividual, and intra-individual variation in the flower characters of Iberian pear Pyrus bourgaeana (Rosaceae). Oecologia 169:713-722 